\title{
Correction to: Parental Status and Biological Functioning: Findings from the Nashville Stress and Health Study
}

\author{
Reed T. DeAngelis ${ }^{1} \cdot$ John Taylor $^{2}$ D $\cdot$ Katherine L. Friedman ${ }^{3}$
}

Published online: 10 August 2020

(c) Springer Nature B.V. 2020

\section{Correction to: Population Research and Policy Review (2020) 39:365-373 https://doi.org/10.1007/s11113-019-09534-1}

Unfortunately, due to an error upon submission of this article, the article was published with an incomplete author group. Dr. Katherine L. Friedman was not listed as third author of this paper. With this correction Dr. Katherine L. Friedman has been added to the author group.

Publisher's Note Springer Nature remains neutral with regard to jurisdictional claims in published maps and institutional affiliations.

The original article can be found online at https://doi.org/10.1007/s11113-019-09534-1.

John Taylor

jrtaylor@fsu.edu

1 University of North Carolina at Chapel Hill, Chapel Hill, USA

2 Department of Sociology, Florida State University, 526 Bellamy Building, Tallahassee, FL 32306-2270, USA

3 Department of Biological Sciences, Vanderbilt University, Box 351634 Station B, , Nashville, TN 37235-1634, USA 